\title{
AN UNDERWATER SURVEY ON THE LULWORTH BANKS
}

\author{
BY G. R. FORSTER \\ The Plymouth Laboratory \\ (With Text-fig. I)
}

There are still very few descriptions of the fauna of submerged rocks around British coasts. An opportunity to examine such a rock fauna with the facilities offered by the marine survey section of the Atomic Energy Authority Establishment at Winfrith Heath was therefore most acceptable.

A few exploratory dives were made in November 1959 around Worbarrow Bay in depths of 5-8 fm; but the low rock reefs encountered were generally surrounded by sand which would be expected to cause scouring or even undergo mass shifts during winter gales. The fauna in this area might therefore be expected to fluctuate considerably from time to time and would not be suitable for a quantitative survey. Fortunately, thanks to information from $\mathrm{Mr} \mathrm{A}$. H. Stride of the National Institute of Oceanography, my attention was drawn to the Lulworth Banks lying 2 miles offshore in Weymouth Bay (see Fig. I) with depths of 8-Io fm. An 'asdic' and core sampling survey had been made by Mr Stride from R.R.S. 'Discovery II' and from his results it was possible to select the roughest rock areas for a second series of dives in August 1960.

The position at which diving was carried out from I5 to I9 August isBats Head bearing $009^{\circ}$ True-distance $2 \cdot 2$ sea miles. The Decca co-ordinates for the position are Red G 5.95: Purple G 56.55. The following transits were also noted: (I) two trees just showing in the Arish Mell gap, between the junction of Rings Hill on the right and Bindon Hill on the left; (2) a pair of beacons on the cliffs at Ringstead Bay in line; (3) the Hardy monument in line with a house on the right of a conspicuous white house, presumably South Down dairy.

These marks can be verified by reference to Admiralty Chart No. 26Io. The diving position was temporarily fixed with a marker buoy. The depth was $9 \frac{1}{2} \mathrm{fm}$ at low water (neaps). The sea bed is rocky, apparently limestone with occasional pockets of sand or gravel. On the rock surface there is a very little fine silt deposited wherever shelter is afforded by algal holdfasts or by the various encrusting animals. 
General description of the fixed fauna and flora

Small red algae and fine branched Bryozoa covered most of the rock surface. The algae were thickest on any elevated rocks or reefs, while the Bryozoa predominated on any sloping surfaces. A sample of the algae was identified by Dr A. D. Boney. Calliblepharis ciliata (Huds.) Kütz. and Brongniartella byssoides (Good. et Woodw.) Schm. were particularly abundant; two other species Chondria dasyphylla (Woodw.) Ag. and Nitophyllum sp. (bonnemaisonii?) also occurred. The commonest Bryozoa were Crisia denticulata (Lamarck), Cellaria fistulosa Hinks. Among the sponges Polymastia boletiformis was very common. Cliona celata Grant (massive form), Raspailia hispida (Montagu) and Pachymatisma johnstonia (Bowerbank) were also frequently met with.

\section{Quantitative survey}

A quantitative survey was undertaken by the method previously used for Echinus (Forster, 1959). A terylene rope $34 \mathrm{~m}$ long is stretched out on the sea bed, the diver then swims along with a $2 \mathrm{~m}$ measuring rod recording the numbers of certain species which lie in the area covered by the rod. The count is made on each side of the terylene rope and therefore the total area covered is $4 \times 34=136 \mathrm{~m}^{2}$. The species selected for counting were: Polymastia boletiformis-sponge, Bispira volutacornis (Montagu)—sabellid worm, and Lepralia foliacea (Ellis \& Sol.) - bryozoan. The three species were all fairly common and easily recognized. Lepralia presented some difficulty as the colonies varied in size from 3 in. diam. to about 18 in.; it was therefore necessary to make some estimate of the size of each colony. All notes were made in pencil on a sheet of 'Cobex' matt-surfaced P.V.C. The position of the different survey lines is shown on Fig. I and the results in Table I. A total of six counts was undertaken. Position 3 has obviously by far the lowest numbers: it was in fact located on a different type of bottom. Instead of the irregular limestone rock the surface was remarkably flat, in the form of a low reef with very little gradient, probably composed of hardened clay. At the edge of this reef was an extensive area of coarse sand. Flustra foliacea (L.) was abundant on the reef surface together with large numbers of small scallops, Chlamys opercularis (L.); the scallops swam away in front of the diver in a continuous diverging wave. The close proximity of the sand probably accounts for the different fauna. Apart from 3 the other five positions show reasonable agreement in the number of the three species. If the results were averaged one would expect to find eight Polymastia, four Bispira and two Lepralia colonies in $\mathrm{Io} \mathrm{m}^{2}$ of rock surface.

Compared to similar areas near Plymouth there was a notable absence of Laminaria hyperborea (Gunn.) Fosl. which appeared only close inshore, on rocks raised up 3 or $4 \mathrm{ft}$ from the surrounding reef, at 4-5 fm depth. 
Echinus esculentus L. was also absent and only one single Eunicella verrucosa was observed. Bispira was very much more common than at Plymouth, frequently living in holes in the rock provided by boring molluscs. Dr Eve Southward has identified many copepods which she found on the arms of Bispira as Gastrodelphys clausii Graeffe.

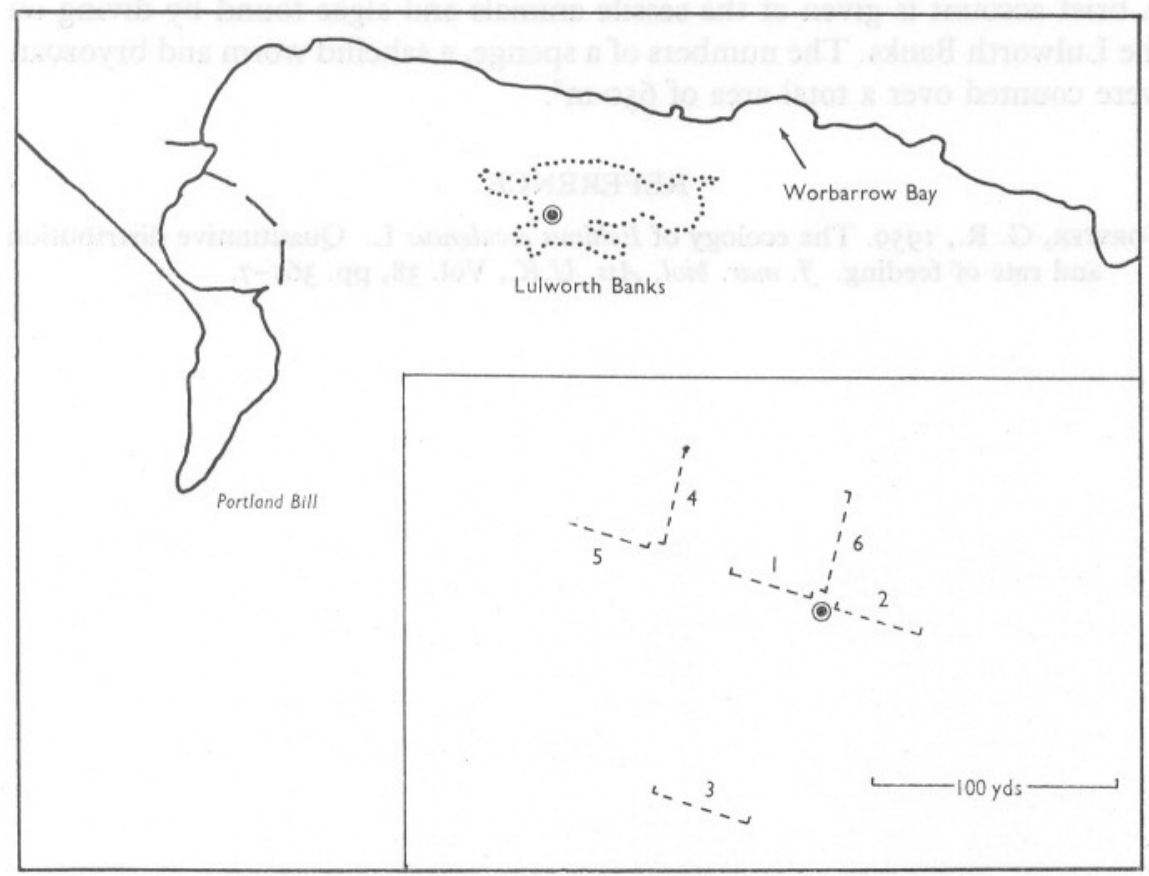

Fig. I. The outline of Weymouth Bay showing (dotted) the ro fm contour around Lulworth Banks and the diving positions. The large-scale insert shows the approximate positions of the counts $I-6$.

TABLE 1. NUMBERS OF SELECTED SPECIES COUNTED ON THE SEA BED

\begin{tabular}{|c|c|c|c|c|c|c|c|c|c|}
\hline \multirow{2}{*}{$\begin{array}{c}\text { Survey } \\
\text { no. }\end{array}$} & \multirow[b]{2}{*}{ Polymastia } & \multirow[b]{2}{*}{ Bispira } & \multicolumn{5}{|c|}{ Lepralia colonies } & \multirow{2}{*}{$\begin{array}{c}\text { Total } \\
\text { Lepralia }\end{array}$} & \multirow{2}{*}{$\begin{array}{c}\text { Area } \\
\text { covered } \\
\left(\mathrm{m}^{2}\right)\end{array}$} \\
\hline & & & I 8 in. & 12 in. & 9 in. & 6 in. & 3 in. & & \\
\hline I & I73 & 39 & I & I & I2 & I & 6 & $2 \mathrm{I}$ & I36 \\
\hline 2 & 97 & $8 \mathrm{I}$ & I & I & 8 & 2 & I0 & 22 & I36 \\
\hline 3 & II & 8 & 2 & ० & I & I & 5 & 9 & 130 \\
\hline 4 & 105 & 30 & I & 0 & 2 & 3 & 5 & I I & II 2 \\
\hline 5 & 67 & 36 & I & 0 & 6 & 9 & I4 & 30 & 136 \\
\hline 6 & 95 & 86 & I & 3 & 5 & IO & 3 & 22 & I36 \\
\hline $\begin{array}{l}\text { Total } \\
\text { (excl. 3) }\end{array}$ & 3) 537 & 272 & 5 & 5 & 33 & 25 & 38 & 106 & 656 \\
\hline Mean & $8 \cdot 19$ & $4 \cdot 15$ & - & - & - & - & - & $I \cdot 6 I$ & 一 \\
\hline
\end{tabular}


I am most indebted to Mr D. J. Scarratt and Mr R. E. Joyce for assistance with diving and with handling the heavy gear; also to the marine survey section of the Winfrith Heath Atomic Energy Research Station for providing a vessel.

\section{SUMMARY}

A brief account is given of the sessile animals and algae found by diving on the Lulworth Banks. The numbers of a sponge, a sabellid worm and bryozoan were counted over a total area of $650 \mathrm{~m}^{2}$.

\section{REFERENCE}

ForsteR, G. R., 1959. The ecology of Echinus esculentus L. Quantitative distribution and rate of feeding. F. mar. biol. Ass. U.K., Vol. 38, pp. 36I-7. 